\title{
Early Modern Cultures \\ of Translation
}


This page intentionally left blank 


\section{Early Modern Cultures of Translation}

Edited by

Karen Newman and Jane Tylus

PUBLISHED IN COOPERATION WITH

FOLGER SHAKESPEARE LIBRARY

\section{$\overline{\text { PENN }}$}

UNIVERSITY OF PENNSYLVANIA PRESS

P H ILADELPHIA 
Copyright (C) 2015 University of Pennsylvania Press

All rights reserved. Except for brief quotations used for purposes of review or scholarly citation, none of this book may be reproduced in any form by any means without written permission from the publisher.

$$
\begin{gathered}
\text { Published by } \\
\text { University of Pennsylvania Press } \\
\text { Philadelphia, Pennsylvania I9I04-4II2 } \\
\text { www.upenn.edu/pennpress }
\end{gathered}
$$

Printed in the United States of America on acid-free paper IO 98776543221

Library of Congress Cataloging-in-Publication Data

Early modern cultures of translation / edited by Karen Newman and Jane Tylus.

\section{pages $\mathrm{cm}$}

Includes bibliographical references and index.

ISBN 978-0-8I22-4740-4

I. Translating and interpreting-History-I6th century-Case studies.

2. Translating and interpreting-History- I7th century-Case studies.

3. Translating and interpreting-History—-18th century-Case studies.

4. Translations-Publishing-History-I6th century-Case studies.

5. Translations-Publishing-History-I7th century-Case studies.

6. Translations-Publishing-History-I8th century-Case studies.

7. Literature-Early modern, I500-1700-Translations-History and criticism-Case studies. I. Tylus, Jane, editor. II. Newman, Karen, editor.

P306.2.EI7 20I5

4I8'.0209-dc23 